\title{
UPAYA PENDIDIKAN AKHLAK DI SMA MUHAMMADIYAH KABUPATEN SAMBAS KALIMANTAN BARAT
}

\author{
Sapuadi \\ Institut Agama Islam Negeri Palangkaraya \\ sapuadi@iain-palangkaraya.ac.id
}

Nuraini

Institut Agama Islam Sultan Muhammad Syafiuddin Sambas nurainimualimin@gmail.com

\begin{tabular}{ll}
\hline Abstrak \\
\hline Article History & This study aims to explain about moral \\
Received : 15-02-2019 education efforts in Sambas High \\
Revised :16-02-2019 & School Muhammadiyah students. This \\
Accepted:18-02-2019 & research is a field research using \\
\hline Keywords: & qualitative data analysis. the results of \\
Moral Education & the study that the efforts made in the \\
& formation and moral development of \\
& students in Sambas Muhammadiyah \\
& High School used two approaches. \\
& First, through a habituation approach. \\
& Habitual activities in schools such as \\
& performing the midnight prayer in \\
& congregation, carrying out reading the \\
& Qur'an, reading prayers before \\
& learning and after study, habituating \\
& to shaking hands when students meet \\
& with the teacher. Second, through the \\
& exemplary approach. Teachers who \\
& teach at Sambas Muhammadiyah High \\
& School try to be good teachers and can \\
provide good examples of their & students. This example is done to \\
create generations that have good \\
morals.
\end{tabular}




\section{Pendahuluan}

Pendidikan adalah usaha yang dilakukan dengan sengaja dan sistematis untuk memotivasi, membina, membantu, serta membimbing seseorang mengembangkan segala potensi siswa sehingga mencapai kualitas diri yang lebih baik. Inti dari pendidikan adalah pembentukan karakter kedewasaan atau usaha pendewasaan manusia seutuhnya lahir dari batin, baik oleh orang lain maupun oleh dirinya sendiri, dalam arti tuntutan yang menuntut agar peserta didik memiliki kemerdekaan berpikir, merasa, berbicara, dan bertindak serta percaya diri dengan penuh rasa tanggung jawab dalam setiap tindakan dan perilaku kehidupannya sehari-hari. Sedangkan Islam itu sendiri adalah suatu ajaran agama yang menjamin umatnya untuk mencapai kebahagian dunia serta akhirat dengan berdasarkan Al-Qur'an dan Al-Hadits (Yayan, 2011: 14).

Berbagai macam problem remaja banyak bermunculan baik melalui media televisi maupun media cetak. Diantara problematika tersebut seperti banyaknya remaja meniru budaya asing, melakukan tindakan kriminal bahkan juga menggunakan obat-obatan terlarang . Problem yang dihadapi remaja merupakan proses dalam mencari jati diri untuk mencapai kematangan dalam bertindak sehingga batasan usia juga menentukan dari usia anak-anak ke remaja. Berbagai macam krisis akhlak dan moral juga kini terus menerpa dalam masyarakat Indonesia, khususnya di kalangan remaja. Remaja yang seharusnya belajar, memanfaatkan masa remajanya dengan berbagai aktivitas positif, berkarya, kreatif dan meningkatkan kemampuan sesuai minatnya justru malah terjebak pada berbagai perilaku yang menyimpang. Realitas di masyarakat menunjukkan bahwa tidak sedikit di antaranya yang cenderung berprilaku kurang menyenangkan atau melakukan perbuatan yang seharusnya tidak mereka lakukan. Perilaku tersebut, seperti premanisme, pergaulan bebas, miras, penyalahgunaan narkoba.

Berdasarkan data hasil penelitian yang dilakukan beberapa lembaga menunjukkan sebuah keadaan yang sangat menghawatirkan terkait dengan perkembangan perilaku menyimpang yang dilakukan golongan remaja dari tahun ke 
tahun. Data dari Kemenpora RI menunjukkan bahwa pengguna narkoba di Indonesia sebanyak 3,6 juta orang, pengguna narkoba berasal dari kalangan pelajar, mahasiswa, rumah tangga, politisi sampai aparat pemerintahan. Hasil survey BNN dan Puslitkes UI setiap tahun jumlah pengguna narkoba terus bertambah, peredaran terbesar narkoba : 1) Pontianak $(29,7 \%)$; 2) Jogjakarta $(14 \%)$; 3) Jakarta $(12 \%)$; 4) Medan $(8,6 \%)$; 5) Surabaya $(7,6 \%)$; 6) Makasar $(6,8 \%)$, (Komenpora RI Tahun 2013).

Terjadinya tindakan dan perilaku tersebut menunjukkan betapa seriusnya krisis akhlak yang melanda remaja saat ini dan disinyalirkan sebagai akibat dari tidak berhasilnya pembinaan akhlak dan budi pekerti pada remaja. Kegagalan pembinaan akhlak akan menimbulkan masalah yang sangat besar, bukan saja pada kehidupan bangsa saat ini tetapi juga masa yang akan datang. Oleh karena itu, tindakan dan perilaku yang menyimpang tersebut harus segera diselesaikan. Pada tataran ini sekolah sebagai lembaga pendidikan formal memainkan peranan penting dalam pembinaan akhlak remaja.

Pentingnya pembinaan Akhlak siswa yaitu dengan memberikan bimbingan, pengawasan dan pengajaran akhlak pada siswa, dengan tujuan supaya siswa bisa membedakan mana akhlak yang baik dan mana akhlak yang buruk. Dengan demikian siswa akan paham dan mengerti bahwa perbuatan yang baiklah yang harus mereka kerjakan. Dalam pembinaan akhlak baik di lingkungan keluarga maupun lingkungan sekolah, hal yang pertama yang harus dilakukan adalah penguatan akidah pada diri peserta didik. Hal ini dikarenakan akidah merupakan fondasi awal dalam membentuk kepribadian yang baik. Jika kuat fondasinya maka akan kuat juga bangunan akhlak yang ada pada diri seseorang. Model pembinaan ini telah dicontohkan oleh Lukmanul Hakim, sebagaimana yang telah diceritakan dalam Al-Qur'an :

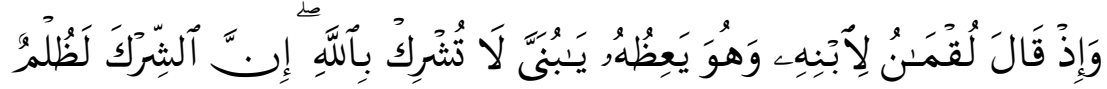


Artinya : Dan (ingatlah) ketika Luqman berkata kepada anaknya, di waktu ia memberi pelajaran kepadanya: "Hai anakku, janganlah kamu mempersekutukan Allah, Sesungguhnya mempersekutukan (Allah) adalah benar-benar kezaliman yang besar (QS Luqman ayat 13).

Guru adalah seseorang yang seharusnya dicintai dan disegani oleh muridnya, penampilannya dalam mengajar haruslah menyakinkan dan tindak tanduknya akan ditiru dan diikuti oleh muridnya. Guru merupakan tokoh yang akan ditiru dan diteladani, dalam melaksanakan tugasnya sebagai pendidik, ia harus tabah dan tahu cara memecahkan berbagai kesulitan dalam tugasnya sebagai pendidik, (Rusiadi, 2012: 63). Ini tugas yang sangat penting, bahkan membina akhlak merupakan inti dari ajaran Islam. Rasulullah SAW bersabda yang diriwayatkan oleh Ahmad :

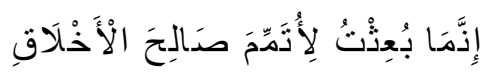

Artinya : Sesungguhnya aku diutus untuk menyempurnakan akhlaq yang mulia (H.R Ahmad)

Peranan guru untuk membentuk akhlak karimah siswa tentunya tidak pernah terlepas dari pengaruh lembaga pendidikan baik sekolah maupun instansi pemerintahan yang terkait guna mendukung dan mengarahkan guru tersebut dalam membina siswanya. Keberhasilan seorang guru dalam membina akhlak siswa akan berbanding lurus terhadap dukungan dari sekolah tempat guru tersebut mengajar. Oleh karena itu pihak lembaga pendidikan khususnya sekolah sangat dituntut untuk senantiasa memberikan dukungan baik materil maupun moril terhadap upaya maupun program yang dilakukan oleh guru dalam membina akhlak siswa sepanjang tidak bertentangan dengan hukum dan tidak memberatkan. Di dalam UndangUndang juga dicantumkan tujuan tentang tujuan pendidikan nasional sebagai berikut :

Pendidikan Nasional bertujuan untuk mencerdaskan kehidupan bangsa serta mengembangkan potensi peserta didik agar menjadi manusia yang beriman dan bertakwa terhadap Tuhan yang Maha Esa dan berbudi pekerti luhur, memiliki pengetahuan dan keterampilan, sehat jasmani 
dan rohani kepribadian yang mantap, menjadi warga negara yang demokratis serta bertanggung jawab.

Ini usaha dan sekaligus tujuan pendidikan nasional yang menjadikan tugas dari guru sebagai pemegang peran utama, menjadi guru dibutuhkan kepribadian yang baik dan berakhlakul karimah. Guru adalah ujung tombak dalam proses belajar mengajar yang ikut berperan dalam usaha pembentukkan akhlakul karimah. Akhlak guru mempunyai pengaruh yang besar sekali pada akhlak-akhlak siswa. Oleh karena guru menjadi contoh teladan bagi siswa, maka guru harus berpegang teguh dengan ajaran agama, serta berakhlak mulia berbudi luhur dan penyayang kepada siswanya (Sudirman, 2005: 67).

Melihat kenyataan tersebut, maka peneliti tertarik untuk meneliti dan membahas masalah tentang upaya pembinaan akhlak siswa di SMA Muhammadiyah Sambas.

\section{Metode Penelitian}

Penelitian ini dilakukan di SMA Muhammadiyah Sambas. Penentuan dalam pemilihan setting ini lebih menitikberatkan pada pertimbangan program pembinaan akhlak siswa yang sangat intensif untuk menciptakan generasi-generasi yang memiliki akhlak yang baik. Selain itu SMA Muhammadiyah Sambas juga merupakan sekolah dengan tingkat kelulusan diatas 90 persen sejak tahun 2011. Menurut Sabarguna (2008:4), penelitian kualitatif merupakan upaya yang mendalam dan memakan waktu berhubungan dengan lapangan dan situasi nyata. Menurut Satria (2009:99), penelitian kualitatif digunakan untuk menjawab pertanyaan apa, mengapa atau bagaimana dan strategi pengumpulan data dengan langkah pengumpulan dokumen, pengamat berperan serta, wawancara tidak struktur dan informal, mencatat data dalam catatan lapangan secara intensif.

Data dalam penelitian ini didapatkan melalui tiga cara. Pertama, melalui observasi. Menurut Bimo Walgito (1994:31), observasi adalah suatu metode penelitian yang dilakukan dengan sengaja secara sistematis dengan menggunakan alat indera sebagai alat untuk menangkap secara langsung kejadiankejadian pada saat peristiwa itu terjadi. Kedua, melalui 
wawancara. Menurut Arikunto (1998:155), wawancara adalah dialog yang dilakukan pewawancara dari terwawancara dalam mengumpulkan data dan informasi dengan cara memberikan pertanyaan-pertanyaan dalam bentuk lisan secara terstruktur dan sistematis. Wawancara digunakan oleh peneliti untuk memperoleh informasi langsung dari sumbernya. Informasi tersebut didapat dari komunikasi dengan sumber data melalui dialog secara lisan secara langsung. Ketiga, melalui dokumentasi. Arikunto (1998:135), menyatakan bahwa dokumentasi berasal dari kata dokumen yang artinya barang tertulis. Dengan demikian, teknik dokumentasi dalam penelitian ini adalah suatu teknik pengumpulan data melalui buku-buku, arsip, catatan harian dan dokumen lainnya. Teknik dokumentasi peneliti dijadikan sebagai data pelengkap dari sumber data yang ada.

\section{Hasil dan Pembahasan}

Upaya Pembinaan Akhlak di SMA Muhammadiyah Sambas

Menurut bahasa akhlak ialah bentuk jamak dari kata khuluq (khuluqun) yang berarti budi pekerti, perangai, tingkah laku atau tab'iat. Akhlak disamakan dengan kesusilaan, sopan santun. Dalam bahasa Yunani khuluq disamakan dengan kata ethicos atau ethos yang berarti adab kebiasaan, perasaan batin, kecenderungan hati untuk melakukan perbuatan. Ethicos kemudian berubah menjadi etika (Abdullah, 2008:2).

Menurut istilah, para ahli berbeda pendapat, namun intinya sama yaitu tentang perilaku manusia. Pendapat para ahli tersebut di antaranya ialah Ibrahim Anis dan al-Ghazali. Ibrahim Anis mengatakan akhlak adalah ilmu yang objeknya membahas nilai-nilai yang berkaitan dengan perbuatan manusia, dapat disifatkan baik dan buruknya. Menurut alGhazali Akhlak adalah suatu sifat yang tertanam dalam jiwa yang menimbulkan perbuatan-perbuatan dengan mudah tanpa difikirkan dan dipertimbangkan terlebih dahulu (Ismail, 2014: 156).

Pendidikan adalah usaha berupa bimbingan untuk mengembangkan dan menyeimbangkan potensi jasmaniah dan 
ruhaniah. Usaha tersebut di dasarkan pada ajaran agama dengan berpedoman pada al-Qur'an dan sunnah. Usaha tersebut untuk membentuk dan mancapai kepribadian muslim, yaitu kepribadian yang di dalamya tepatri nilai-nilai Islam sehingga segala perilakunya selaras dengan nilai-nilai Islam (Wiyani dan Barnawi, 2016:24).

Pembinaan akhlak terhadap siswa di SMA Muhammadiyah Sambas dilakukan dengan tujuan untuk menghasilkan lulusan yang memiliki kepribadian yang mulia serta bermanfaat untuk kemaslahatan masyarakat. Oleh karena itu pembinaan akhlak dipandang sangat penting di SMA Muhammadiyah Sambas. Atas dasar itu juga berbagai program dan pendekatan yang telah dilakukan untuk memaksimalkan upaya pembinaan akhlak di SMA Muhammadiyah Sambas.

Ada dua pendekatan yang digunakan dalam pembinaan akhlak siswa di SMA Muhammadiyah Sambas. Pertama, pendekatan Pembiasaan. Pendekatan pembiasaan, bisa melalui kegiatan-kegiatan yang ada di sekolah seperti melaksaanakan shalat dzuhur berjamaah, melaksanakan baca Al-Qur'an, membaca doa sebelum belajar dan sesudah belajar, pembiasa an berjabat tangan ketika siswa bertemu dengan guru, kegiatan ini dilakukan untuk membentuk kepribadian siswa sehingga mencerminkan akhlak dan sikap dalam menjalin hubungan yang baik.

Pembiasaan memainkan peranan penting dalam pembentukan akhlak seorang siswa. Melalui pembiasaan ini, anak didik akan terbiasa untuk melakukan berbagai perilaku dan ucapan yang positif. Selain itu, pembiasaan juga dapat dipandang sebagai sebuah latihan yang terus menerus dilakukan agar terbentuk perilaku, perkataan, dan sikap yang sesuai norma sosial yang berlaku. Pembiasaan dalam pendidikan amat dibutuhkan karena secara psikologis, setiap pengetahuan atau tingkah laku yang diperoleh dengan pembiasaan akan sangat sulit mengubah atau menghilangkannya sehingga cara ini amat berguna dalam mendidik anak. Menurut Arief (2002:110) sebagai awal dalam proses pendidikan, pembiasaan merupakan cara yang sangat efektif dalam menanamkan nilai-nilai moral ke dalam jiwa anak. Nilai-nilai yang tertanam dalam dirinya ini kemudian 
akan termanifestasikan dalam kehidupannya semenjak ia mulai melangkah ke usia remaja dan dewasa.

Kedua, pendekatan keteladanan. Pendekatan keteladanan, guru Pendidikan Agama Islam juga berusaha untuk menjadi guru yang baik dan bisa memberikan contoh yang baik terhadap siswa. Guru merupakan teladan bagi peserta didiknya dalam lingkungan sekolah selain orang tua. Dalam pandangan Ulwan (1992:2) guru adalah figur terbaik dalam pandangan peserta didik sehingga segala tindak tanduknya akan menjadi perhatian dan panutan bagi siswanya. Oleh karena itu menurut Marimba (1962:85), guru hendaknya menjaga dengan baik perbuatan maupun ucapannya agar memberikan contoh yang baik juga kepada anak didiknya. Selain itu dalam Darajat (1997:61), memandang bahwa secara psikologi jika seorang anak didik melihat sesuatu yang baik dari orang tua maupun gurunya maka secara tidak langsung hal tersebut merupakan bagian dari proses pembentukan akhlak dan kejiwaan seorang anak didik.

Membangun peradaban sebuah bangsa pada hakikatnya adalah pengembangan watak dan karakter manusia unggul dari sisi intelektual, spiritual, emosional, dan fisikal yang dilandasi oleh fitrah kemanusiaan. Fitrah adalah titik tolak kemuliaan manusia, baik sebagai bawaan seseorang sejak lahir atau sebagai hasil proses pendidikan. Terlepas dari persoalan kuantitatif maupun kualitatif tersebut, dalam konteks pembangunan akhlak melalui sektor pendidikan, guru merupakan pemegang peran yang amat sentral dalam proses pendidikan.

Nilai-nilai akhlak seperti kepedulian, kejujuran, keadilan, tanggung jawab, dan toleransi harus menjadi konsentrasi utama seorang guru dalam membina akhlak siswa. Guru Pendidikan Agama Islam juga harus berkomitmen untuk mengembangkan karakter peserta didik berdasarkan nilai-nilai yang dimaksud serta mendefinisikannya dalam bentuk perilaku yang dapat diamati dalam kehidupan sekolah sehari-hari. Hal lain yang tidak kalah penting adalah semua komponen sekolah bertanggung jawab terhadap standar-standar perilaku yang konsisten sesuai dengan nilai-nilai yang berlaku. 
Upaya untuk mencapai keberhasilan pembinaan akhlak di Sekolah sangat ditentukan oleh kompetensi seorang guru. Pembinaan akhlak oleh Seorang guru yang benar-benar berkompeten akan membuat tujuan pembinaan akhlak di Sekolah tercapai dengan baik. Maka oleh karena itu, Ada empat macam kompetensi guru professional yang harus dimiliki oleh seorang guru seperti yang terdapat dalam Lampiran Peraturan Menteri Pendidikan nasional 16 tahun 2007.

Pertama, kompetensi Padagogik yaitu meliputi pemahaman terhadap peserta didik, perencanaan dan pelaksanaan pembelajaran, evaluasi hasil belajar dan pengembangan peserta didik untuk mengaktualisasikan berbagai potensi yang dimilikinya. Kedua, kompetensi Kepribadian yaitu kemampuan guru mencerminkan kepribadian yang mantap, stabil, dewasa, arif dan berwibawa, menjadi teladan bagi peserta didik dan ber akhlak mulia. Ketiga, kompetensi Sosial yaitu kemapuan untuk berkomunikasi dan bergaul secara efektif dengan peserta didik, sesama pendidik, tenaga pendidik,tenaga kependidikan orang tua/wali peserta didik dan masyarakat. Keempat, kompetensi Profesional yaitu kemampuan untuk menguasai materi pembelajaran secara luas dan mendalam yang mencakup penguasaan materi kurikulum di sekolah dan subtansi keilmuan yang menaungi materinya,serta penguasaan terhadap sturuktur dan metodologi keilmuannya.

1. Pelaksanaan Pembinaan Akhlak di SMA Muhammadiyah Sambas

Pelaksanaan pembinaan akhlak di Sekolah merupakan ujung tombak dari upaya untuk menghasilkan siswa yang berakhlak mulia. Proses pelaksanaan pembinaan tersebut harus terintegrasi dengan berbagai elemen di lingkungan sekolah seperti orang tua siswa, guru mata pelajaran lain dan lain sebagainya. Kesinambungan pembinaan akhlak antara masingmasing elemen di sekolah akan melahirkan sebuah suasana yang selalu memperhatikan akhlak mulia sehingga secara tidak langsung setiap warga sekolah khususnya para siswa akan terbiasa untuk berakhlak baik.

Menurut al-Ghazali pada dasarnya pendidikan akhlak bertujuan untuk merubah akhlak menjadi akhlak mulia. Ini 
sesuai dengan perintah Nabi saw agar manusia menghiasi akhlaknya dengan akhlak mulia. Perubahan akhlak manusia adalah hal yang mungkin dan dapat terjadi. Berdasarkan pernyataan tersebut dapat dikatakan bahwa pendidikan akhlak terhadap anak adalah tuntutan yang mendasar untuk membina dan membimbing anak agar berakhlak mulia.

Pendidikan akhlak adalah pendidikan yang cenderung membimbing dan menuntun kondisi jiwa manusia sehingga dapat tercipta akhlak dan kebiasaan yang baik yang sesuai dengan syariat agama dalam kaitannya dengan sang Pencipta (Allah) dan sesama manusia dan alam sekitar (Faj, 2012:110).

Temuan di lapangan menunjukkan bahwa pelaksanaan pembinaan akhlak siswa SMA Muhammadiyah Sambas dilakukan dengan dua cara. Pertama, melalui kegiatan intra dan ekstra kurikuler. Kegiatan intrakurikuler yaitu pendidikan agama, disiplin waktu atau belajar dan pembiasaan berjabat tangan ketika siswa bertemu dengan guru sedangkan kegiatan ekstrakurikuler seperti pelaksanaan shalat dzuhur berjamaah, pesantren kilat, program sekolah sehat, pembinaan pramuka, nasid dan baca Al-Qur'an. Pembinaan akhlak siswa melalui kegiatan ekstrakurikuler pada dasarnya merupakan bagian dari transformasi dan internalisasi nilai-nilai akhlak dalam kegiatan yang mendidik. Dalam kegiatan ekstrakurikuler tersebut siswa tidak hanya diajarkan untuk aktif dalam mengikuti kegiata, tapi juga dibiasakan dan diajarkan tentang nilai-nilai yang terkandung di dalamnya. Secara tidak langsung nilai-nilai tersebut akan melatih siswa untuk memiliki rasa tanggung jawab dan etika sosial kepada setiap orang yang ditemuinya.

Internalisasi nilai akhlak melalui kegiatan ekstrakurikuler merupakan proses pemantapan dan penanaman keyakinan, sikap, nilai pada diri individu. Melalui proses internalisasi tersebut diharapkan nilai-nilai tersebut menjadi perilakunya (moral behaviour). Ketika perilaku moral seseorang telah berubah, maka bisa dikatakan nilai-nilai itu sudah tertatamkan dalam dirinya. Pada tataran inilah menurut Krathwohl (1973:20) pembentukan moral, karakter atau internalisasi nilai atau penanaman afeksi tidak cukup hanya diajarkan lewat kognisi saja namun juga harus melalui praktek langsung, mereka perlu dibiasakan (habituated) tentang nilai-nilai 
tertentu yang akan ditanamkan. Kedua, melakukan kerjasama dengan guru mata pelajaran lain dan orang tua siswa dalam membina akhlak siswa yang bermasalah. Hal ini dilakukan bertujuan untuk menciptakan generasi-generasi yang memiliki akhlak atau moral yang baik, baik terhadap sesama manusia maupun terhadap lingkungan.

Orang tua merupakan pendidik utama dalam lingkungan keluarga. Oleh karena itu, peran orang tua dalam pembentukan dan pembinaan akhlak seorang anak sangat penting (Uhbiyati, 1998:109). Begitu pentingnya peran orang tua terhadap pembinaan akhlak seorang anak, sehingga untuk keberhasilan upaya pendidikan akhlak pihak sekolah juga harus bekerjasama dengan orang tua siswa. Kewajiban pendidikan akhlak bagi anak pada dasarnya menjadi kewajiban utama bagi setiap orang tua. Namun dengan keterbatasan waktu dan pengetahuan yang dimiliki, maka diperlukan kerjasama antara oranag tua dengan berbagai pihak terutama lembaga pendidikan dan masyarakat dalam membina akhlak anaknya. Meskipun dimungkinkan adanya pemberian tugas untuk membina akhlak anak kepada sekolah, namun tanggung jawab terbesar tetap berada di pundak orang tua. Menurut Wijaya dan Barmawi (2016:69) ada beberapa alasan yang menyebabkan orang tua menyerahkan tanggung jawab pendidikan akhlak anak mereka kepada lembaga pendidikan. Pertama, keterbatasan waktu. Kedua, keterbatasan penguasaan ilmu pengetahuan dan keterampilan mendidik. Ketiga, keterbatasan fasilitas pendidikan. Keempat, efisiensi biaya kebutuhan pendidikan. Kelima, efektivitas program pendidikan dan pembinaan akhlak anak.

\section{Simpulan}

Berdasarkan analisis terhadap hasil penelitian yang telah dilakukan dapat disimpulkan bahwa upaya yang dilakukan dalam pembentukan dan pembinaan akhlak siswa di SMA Muhammadiyah Sambas menggunakan dua pendekatan. Pertama, melalui pendekatan pembiasaan. Kegiatan-kegiatan pembiasaan yang ada di sekolah seperti melaksaanakan shalat dzuhur berjamaah, melaksanakan baca Al-Qur'an, membaca doa sebelum belajar dan sesudah belajar, pembiasaan berjabat tangan ketika siswa bertemu dengan guru. Kedua, melalui 
pendekatan keteladanan. Guru yang mengajar di SMA Muhammadiyah Sambas berusaha untuk menjadi guru yang baik dan bisa memberikan contoh yang baik terhadap siswanya. Keteladan ini dilakukan untuk menciptakan generasi-generasi yang memiliki akhlak yang baik.

\section{DAFTAR PUSTAKA}

A.N Ulwan. 1992. Pendidikan Anak menurut Islam: KaidahKaidah Dasar, Remaja Rosdakarya: Bandung.

A. Arief. 2002. Pengantar Ilmu dan Metodologi Pendidikan Islam, Ciputat Press: Jakarta.

Arikunto, Suharsimi. 1998. Prosedur Penelitian, Rineka Cipta: Jakarta.

Awaluddin Faj. Revitalisasi Pembentukan Moral Generasi Bangsa melalui Pendidikan Islam. Jurnal At-Ta'dib Vol. 7 No. 1 tahun 2012.

Darajat, Zakiah. 1997. Kepribadian Guru. Bulan Bintang: Jakarta.

David R. Krathwohl. Taxonomy of Educational Objective Book II: Affective Domain, Longman Group: London.

Ghoffar Ismail. 2014. Menjadi Muslim Paripurna, Unires Press: Yogyakarta.

Marimba. 1962. Pengantar Ilmu Filsafat, Al-Maarif: Bandung. Novan Ardy Wiyani dan Barnawi. 2016. Ilmu Pendidikan Islam, Ar-Ruzz Media: Yogyakarta.

Ridwan, Yayan. 2011. Ilmu Pengetahuan Islam, Sedaun Anggota IKAPI: Jakarta.

Rusiadi. 2012. Metodologi Pembelajaran Agama Islam, Sedaun: Jakarta. 
Sabarguna, Boy S. 2008. Analisis Data Pada Penelitian Kualitatif, Universitas Indonesia: Jakarta.

Satria, Affan B. 2009. Tips Dan Cara Menyusun Skripsi Tesis Disertasi, Shira Media: Yogyakarta.

Tebba, Sudirman. 2005. Manusia Malaikat, Cangkir Geding: Yogyakarta.

Walgito, Bimo. 1994. Penelitian Masyarakat, Rineka Cipta: Jakarta.

Yatimin Abdullah. 2008. Studi Akhlak dalam Perspektif AlQur'an, Amzah: Jakarta. 